View Point

\title{
PRE-BREEDING: A LINK BETWEEN GENETIC RESOURCES AND MAIZE BREEDING
}

\author{
Luciano Lourenço Nass $^{1 *}$; Ernesto Paterniani² \\ ${ }^{1}$ Embrapa Recursos Genéticos e Biotecnologia, SAIN Parque Rural, CEP: 70770-900 - Brasília, DF. \\ ${ }^{2}$ Depto. de Genética, USP/ESALQ, C.P. 83 - CEP: 13418-900 - Piracicaba, SP. \\ ${ }^{*}$ Corresponding author <llnass@cenargen.embrapa.br>
}

\begin{abstract}
Activities related to genetic resources are characterized by high cost and long term return. Thus the conservation of genetic variability for the future and the efficient utilization of available accessions are two important goals to be attained. However, the low utilization of germplasm banks is not restricted to Brazil but to other developing countries as well. Therefore, pre-breeding is a promising alternative to link genetic resources and breeding programs. Several aspects for maize are discussed such as concept, importance, methods and results. Problems to be investigated and suggestions are also presented.
\end{abstract}

Key words: Zea mays, pre-breeding, genetic resources

\section{PRÉ-MELHORAMENTO: UMA PONTE ENTRE OS RECURSOS GENÉTICOS E O MELHORAMENTO DE MILHO}

\begin{abstract}
RESUMO: As atividades relacionadas com recursos genéticos são caracterizadas por alto custo e retorno a longo prazo. Além da conservação da variabilidade genética para o futuro, a utilização atual dos acessos disponíveis é outro importante objetivo. Entretanto, a utilização de bancos de germoplasma é baixa não apenas no Brasil, mas em outros países em desenvolvimento. Assim, o pré-melhoramento constitui excelente alternativa para tornar os recursos genéticos disponíveis para os programas de melhoramento. Vários aspectos são discutidos como conceito, importância, métodos e resultados no melhoramento de milho. Problemas a serem investigados e também sugestões são apresentadas.

Palavras-chave: Zea mays, pré-melhoramento, recursos genéticos
\end{abstract}

\section{INTRODUCTION}

Maize (Zea mays L.) is a genetically highly studied plant species, consequently, the inheritance of several characteristics and its genome are well known. Some factors for the key position of maize among panmitic species are : economic value, genetic diversity and variability, well identified by its ten chromosomes, facility to obtain large number of seeds from controlled (self and outcross) pollination and facility to obtain different types of progenies. Also, many outstanding scientists devoted their life to the study of both basic and applied research. As a result, most breeding methods for allogamous species have been developed initially in maize.

About 300 races of maize have been recognized in the Western Hemisphere. Brieger et al. (1958) and Paterniani \& Goodman (1977) described and evaluated the genetic potential for races of maize in Brazil and adjacent areas. Approximately $50 \%$ of these races are adapted to low altitudes $(0-1000 \mathrm{~m}), 10 \%$ to intermediate (1000 $2000 \mathrm{~m}$ ), and $40 \%$ to higher altitudes (>2000 m). Regarding to endosperm type $40 \%$ are floury, $30 \%$ are flints, $20 \%$ are dents, less than $10 \%$ are popcorns, and almost $3 \%$ are sweetcorns (Paterniani \& Goodman, 1977). It is estimated that about 100,000 accessions of maize are maintained in germplasm banks around the world (Chang, 1992). In 1994, the International Maize and Wheat Improvement Center (CIMMYT) Maize Germplasm Bank had in storage nearly 11,000 accessions in its base and active collections. Over the next two decades, the bank will eventually reach from 30,000 to 35,000 accessions (Taba, 1994).

The ultimate purpose of the genetic banks is their use for further genetic improvement of the species. Considering the great genetic diversity existing within the maize species, and the amount of available accessions, it seems pertinent to consider the most desirable approach to achieve the germplasm bank's goals. The objectives of this paper are (1) discuss the role of pre-breeding programs as a link between genetic resources and maize breeding, and (2) review alternatives to improve the use of germplasm in maize breeding.

\section{GENETIC RESOURCES AND PLANT BREEDING}

Activities related to genetic resources are characterized by high cost and long term return. Introduction and germplasm exchange, collection, characterization, evaluation, documentation and conservation are essential steps that can not be overemphasized. An appropriate synchronism among 
these activities is required for the bank to be effective in maintaining genetic variability and to assure germplasm utilization.

The importance of genetic resources is widely recognized. Activities in germplasm banks demand qualified researchers in several areas of knowledge. Besides the conservation of genetic variability for the future, the actual utilization of available accessions is another important goal. However, the low utilization of germplasm banks is a rule world wide and is not restricted to Brazil or to other developing countries (Nass et al., 1993). The main factors responsible for the low utilization of plant genetic resources are lack of documentation and adequate description of collections, lack of the desired information by breeders, accessions with restricted adaptability, insufficient plant breeders particularly in developing countries and lack of collections evaluations. Low seed availability due to inadequate seed regeneration programs is another barrier to their use (Dowswell et al., 1996). Furthermore, breeder-to-breeder exchange materials is very common and constitutes a reasonable alternative to extend genetic variability in breeding programs. In general, it seems that breeders are satisfied with the available genetic variability among agronomically advanced materials (Duvick, 1984; Paterniani, 1987; Peeters \& Galwey, 1988; Nass et al., 1993). According to Troyer (1990) actually elite inbred lines are considered the best genetic resources simply because each line contains a combination of genetic traits that satisfies the marketplace.

Despite the great available diversity in maize, breeders have concentrated their efforts on a few races (Brown, 1975). Goodman (1990) emphasized that it is almost impossible to identify a widely used U.S. hybrid of parentage that cannot be traced to neither Reid nor Lancaster. Furthermore, about six inbred lines and their close relatives are represented in approximately $70 \%$ of all U.S. hybrids. These inbred lines are C103, Mo17 and Oh43 (Lancaster type lines) and A632, B37 and B73 (Reid type lines).

The search for superior genotypes regarding yielding ability, disease and pest resistance, stress tolerance or better nutritional quality is very hard, competitive and expensive. This is why breeders tend to concentrate to adapted and improved materials, avoiding wild parents, landraces and exotics, available in germplasm banks which would require long time, high financial support besides the difficulty to identify potentially useful genes. Marshall (1989) emphasized that the difficulty to identify useful genes is the main factor responsible for the low utilization of these accessions. Evidently, there is a gap between available genetic resources and breeding program activities. While germplasm banks try to preserve as much as possible the genetic variability to be used by breeders, breeding programs do not explore efficiently the available diversity, relying almost exclusively on their working collection.
It is generally recognized that commercial hybrids stand on a narrow genetic basis (Goodman, 1990). Hybrid maize breeding is a very competitive enterprise and the trend is that this competition is likely to increase. Thus, plant breeders are exploring elite inbred lines since these materials are expected to yield promising results in the short term. In order to secure continuous genetic improvement, maize breeders adopt several ways to obtain new genetic materials. Among these, recently, both public and private programs are using intensively the most improved available materials. In this way, to develop new populations and inbred lines, commercial $F_{1}$ hybrids are being widely used, since this is a legitimate source of parental germplasm (Parks, 1993). However, the recurrent use of these genotypes should increase the narrowness of the genetic base. In a short time, available commercial hybrids probably will be very similar since they partake the same genetic background. Genetic vulnerability must be a constant concern in plant breeding for all species. Theoretical expectations and actual experience show that the use of uniform materials can be dangerous, as occurred with cytoplasm $T$, susceptible to Helminthosporium maydis race $\mathrm{T}$ in the United States in 1970 and next year in other regions of the world.

\section{PRE-BREEDING}

\section{Concept}

Pre-breeding is the most promising alternative to link genetic resources and breeding programs. Prebreeding refers to all activities designed to identify desirable characteristics and/or genes from unadapted (exotic or semi-exotic) materials, including those that, although adapted have been subjected to any kind of selection for improvement. As pre-breeding is being carried out, the resulting materials are expected to have merit to be included in ordinary breeding programs.

Although there are some different concepts of exotics, Hallauer \& Miranda Filho (1988) consider that exotics for pre-breeding purposes include any germplasm that does not have immediate usefulness without selection for adaptation for a given area. In this sense, exotic germplasms are represented by races, populations, inbred lines, etc. Consequently, the results of crosses between adapted and exotic materials, where different proportions of introgression are obtained and evaluated, have been denominated as semi-exotic materials. According to Hallauer (1978), the utilization of semi-exotic populations has been the most common procedure to evaluate exotic germplasms. In order to obtain promising results with exotics their reproduction is necessary for a few generations in order to allow genetic recombination accompanied by mild selection. Before useful recombinants can be selected a minimum of five generations of random mating with mild selection pressure is indicated (Lonnquist, 1974). 


\section{Importance}

Pre-breeding programs can generate new base populations for breeding programs and also assist in identifying heterotic patterns for hybrid programs. Marshall (1989) considered that the lack of pre-breeding programs is the most limiting factor for using landrace germplasms and unadapted exotic lines from collections. Pre-breeding at CIMMYT's Germplasm Bank collections, aims to provide to breeders ready utilization of materials with specific traits of interest as well as a means to broaden the diversity of improved germplasm. Caribbean collections are receiving first priority for pre-breeding efforts, based on the interest of this germplasm both by tropical and temperate maize breeders, and the fact that, evaluations of these collections are already under way (Taba, 1994). As a result of these pre-breeding programs, many gene pools and populations were developed by CIMMYT for tropical lowlands, as shown in TABLE 1.

Clearly pre-breeding programs are time-consuming and tiresome. For private plant breeders, generally under pressure to fulfill short term goals, exotics that underwent pre-breeding are likely to be more useful and certainly more attractive (Smith \& Duvick ,1989). Consequently, close cooperation between public and private institutions can be especially helpful in pre-breeding programs (Smith \& Duvick, 1989; Nass et al., 1993).

Heterotic pattern is a key factor for utilizing germplasm to maximize performance of the populationcrosses and derived hybrids (Eberhart et al., 1995). Prebreeding can identify heterotic patterns for breeeding programs where the goal is hybrid development. Although the heterotic pattern between Lancaster Sure Crop and Reid Yellow Dent has received greatest use in U.S. programs, other heterotic patterns have been considered as Leaming and Midland (Hallauer et al., 1988). Identification of other heterotic patterns should contribute for a broadening of germplasms to be used commercially (Mungoma \& Pollak, 1988). CIMMYT's heterotic patterns are shown in TABLE 2.

Generally, hybrid programs showed good results in tropical areas, especially where the existence of well structured and competitive private companies further contributed to this performance. In Brazil, flint by dent crosses are widely used and usually include materials derived from either Cateto by Tuxpeño or Suwan-1 by Tuxpeño (Hallauer et al., 1988). Paterniani (1990) emphasized the remarkable contribution of the race Tuxpeño to increase the yielding potential of hybrids and open-pollinated varieties in Brazil. Brazilian maize hybrid programs pioneered the commercial utilization of semi-dent types. High levels of heterosis however, are not restricted to crosses involving contrasting endosperm types. Paterniani \& Lonnquist (1963) observed that expressed heterosis was as great between cultivars with similar endosperms as well as between those with contrasting endosperm types. These results indicate genetic variability among germplasms of similar endosperm types.
TABLE 1 - Maize gene pools and populations developed and improved by CIMMYT for tropical lowlands breeding programs. ${ }^{1}$

\begin{tabular}{|c|c|}
\hline $\begin{array}{l}\text { Pools and } \\
\text { Populations }\end{array}$ & Identification \\
\hline & Gene Pools \\
\hline Pool 15 & Tropical Early White Flint \\
\hline Pool 16 & Tropical Early White Dent \\
\hline Pool 17 & Tropical Early Yellow Flint \\
\hline Pool 18 & Tropical Early Yellow Dent \\
\hline Pool 19 & Tropical Intermediate White Flint \\
\hline Pool 20 & Tropical Intermediate White Dent \\
\hline Pool 21 & Tropical Intermediate Yellow Flint \\
\hline Pool 22 & Tropical Intermediate Yellow Dent \\
\hline Pool 23 & Tropical Late White Flint \\
\hline Pool 24 & Tropical Late White Dent \\
\hline Pool 25 & Tropical Late Yellow Flint \\
\hline \multirow[t]{5}{*}{ Pool 26} & Tropical Late Yellow Dent \\
\hline & Tropical White Flint QPM \\
\hline & Tropical White Dent QPM \\
\hline & Tropical Yellow Flint QPM \\
\hline & Tropical Yellow Dent QPM \\
\hline \multicolumn{2}{|r|}{ Maize Populations } \\
\hline Population 21 & Tuxpeño-1 \\
\hline Population 22 & Mezcla Tropical Blanco \\
\hline Population 23 & Blanco Cristalino-1 \\
\hline Population 24 & Antigua Veracruz-181 \\
\hline Population 25 & Blanco Cristalino-3 \\
\hline Population 26 & Mezcla Amarilla \\
\hline Population 27 & Amarillo Cristalino-1 \\
\hline Population 28 & Amarillo Dentado \\
\hline Population 29 & Tuxpeño Caribe \\
\hline Population 30 & Blanco Cristalino-2 \\
\hline Population 31 & Amarillo Cristalino-2 \\
\hline Population 32 & ETO Blanco \\
\hline Population 35 & Antigua Republica Dominicana \\
\hline Population 36 & Cogollero \\
\hline Population 37 & Tuxpeño O2 \\
\hline Population 39 & Yellow QPM \\
\hline Population 40 & White QPM \\
\hline Population 41 & Composite $\mathrm{K} \mathrm{O} 2$ \\
\hline Population 43 & La Posta \\
\hline Population 61 & Early Yellow Flint QPM \\
\hline Population 62 & White Flint QPM \\
\hline Population 63 & Blanco Dentado-1 QPM \\
\hline Population 64 & Blanco Dentado-2 QPM \\
\hline Population 65 & Yellow Flint QPM \\
\hline Population 66 & Yelolw Dent QPM \\
\hline
\end{tabular}

'Extracted from Pandey \& Gardner (1992).

The need to keep the amount of accessions in genetic banks in a manageable number is becoming more evident. In this way, an additional advantage of well succeeded pre-breeding programs is the establishment of core collections. The main goal of the core is to represent the genetic diversity of a crop species and its relatives with a minimum of repetitiveness. Brown (1989a) suggested that the core should consist of about $10 \%$ of the collection, which represents nearly $70 \%$ of the genetic variability. Moreover, the core should not exceed 3,000 
TABLE 2 - Possible heterotic patterns with CIMMYT's populations. $^{1}$

\begin{tabular}{|c|c|}
\hline Populations & Heterotic Patterns \\
\hline 21 & Populations 25 and 32 ; Pool 23 \\
\hline 22 & Population 25 e 32 \\
\hline 23 & Population 49; Pool 20 \\
\hline 24 & Populations 27, 28 and 36; Suwan-1 \\
\hline 25 & Populations 21, 22, 27, 29, 43 and 44; Pool 24 \\
\hline 26 & Population 31; Pool 21 \\
\hline 27 & Populations 24, 25, 28 and 36; Suwan-1 \\
\hline 28 & Populations 24 and 27; Suwan-1 \\
\hline 29 & Populations 25 and 32 \\
\hline 31 & Population 26; Pool 22 \\
\hline 32 & Populations $21,22,29$ and 44 \\
\hline 33 & Population 45 \\
\hline 34 & Populations 42 and 47; Pool 32 \\
\hline 36 & Populations 24 and 27 \\
\hline 42 & Populations $34,43,44$ and 47 \\
\hline 43 & Populations 25,42 and 44 \\
\hline 44 & Populations 25, 32, 42, 43 and 47; Pool 32 \\
\hline 45 & Population 33; Pool 33 \\
\hline 46 & Population 48; Pool 30 \\
\hline 47 & Populations 34,42 and 44 \\
\hline 48 & Population 46 \\
\hline 49 & Population 23; Pool 19 \\
\hline
\end{tabular}

'Extracted from Pandey \& Gardner (1992).

entries. The establishment of these collections does not affect the base collection strategic role that is a source of replacement of the extensive genetic variability of different species (Brown 1989a,b; Vilela-Morales et al., 1997).

It is important to consider that a core collection is a dynamic rather than a static set of accessions. It is possible to introduce new accessions into the core and also replacements due to changes of breeder's needs. CIMMYT has developed efforts to establish maize cores. Results of a Tuxpeño core collection were reported by Crossa et al. (1994) and Taba et al. (1994).

\section{Methods}

There are several alternatives for incorporating useful characteristics into adapted materials. The methodology depends on the heritability, gene action, number of genes involved, heterosis, and genotype $x$ environment interactions. Whenever a superior germplasm is available from ongoing breeding programs, improvement by introgression is usually the least expensive and speedy method for improving the selected pre-breeding accessions (Eberhart et al., 1995).

The ideal proportion of exotics to be incorporated into adapted germplasms has been investigated by several researchers, but so far there is no conclusive information about this question. According to Bridges \& Gardner
(1987), it depends on the breeding goals (short or long term), and also on the performance of both exotics and adapted germplasms. Wellhausen (1965) recommended the incorporation of about $25 \%$ of exotic germplasm into Corn Belt adapted materials. Crossa \& Gardner (1987) reported that populations with $75 \%$ and $100 \%$ of adapted germplasm did not differ in grain yield, being both populations superior to populations with $50 \%$ of adapted germplasm. Different levels of introgression $(0,25$, 50,75 , and $100 \%$ ) were evaluated by Michelini \& Hallauer (1993), who observed that better yields were obtained in crosses with $50 \%$ exotic germplasm, and also suggested the use of the exotic heterotic pattern Suwan-1 and Tuxpeño for further selection in U.S. Corn Belt breeding programs.

Backcrossing is an efficient way to transfer characteristics controlled by one or two genes, although it can be used also for higher number of genes, including quantitative characters. Thus, backcross has been used to improve adaptation of exotic germplasms. Eberhart (1971) suggested that the first backcross to adapted germplasm is the best base population to start selection. Degree of dominance and diversity of the parents affect the optimum number of backcrosses before initiating selection. In general, as the degree of dominance increases and as the parents become more diverse, additional generations of backcrossing before initiation of selection are required (Dudley, 1982). However, if exotic germplasms have been previously selected for adaptability, immediate positive effects can be obtained (Crossa et al.1987; Mungoma \& Pollak, 1988). Considering the probability of fixing alleles, Crossa (1989) observed that if an exotic population has been selected for adaptability and should have high frequency of favorable alleles, the resulting population can be used directly as base population for selection. In the case backcross is used with the adapted parental, then an increase in population size is recommended in order to maintain the previously incorporated favorable alleles.

\section{New base populations}

Another alternative to improve germplasm utilization is the synthesis of new populations and their subsequent introduction into breeding programs. This has been an important CIMMYT's contribution for maize breeding around the world. Several pools have been developed according to specific characteristics such as maturity cycles, climatic zones, grain color and endosperm types (Salhuana, 1987). Crossa et al. (1990) suggested the use of germplasm collections to develop new heterotic populations for reciprocal recurrent selection, both to develop inbred lines and hybrids based on combining ability as well as for introgression into heterotic populations. The collections and/or their derived cross populations could also be improved by intrapopulational methods in order to develop superior open-pollinated varieties. 


\section{Successful examples}

Salhuana (1987) showed an interesting proposal involving scientists from several countries to evaluate maize germplasm. He suggested that the following traits should be taken in a preliminary evaluation : early and final stand, male and female flowering, plant and ear height, broken plants, lodged plants, number of ears per plant (prolificacy), endosperm type, grain color, quality of the ear and yield. In addition to these traits, others may be considered according specific situations. In this way, the author emphasized the importance of the tester choice due to the following reasons: (a) the yield of the accessions per se indicates the level of favorable gene present, but, on the other hand, evaluation of the crosses indicates the contribution of new favorable genes; (b) non-additive genetic action might be important; (c) enables an estimation of the adaptability necessary to the accessions in order to make an appropriate comparison; (d) to establish a new heterotic source.

The potential of exotic germplasms can also be evaluated by diallelic crosses. This mating system provides data to allow the prediction of means and an adequate knowledge of the combining ability of the materials studied. It is also helpful to identify heterotic patterns for hybrid programs. Crossa et al. (1987) pointed out that the knowledge of parentage in heterotic patterns among populations are essential to identify and separate the heterotic groups. Heterotic patterns do not preclude identifying superior crosses within populations, but the chances are greater between populations of identified heterotic patterns (Hallauer et al., 1988). Crossa et al. (1990) evaluated diallelic crosses among seven tropical late maturity populations at seven locations. They observed that inbred lines derived from Population 24 crossed with those from Suwan-1 and Population 36 are likely to result in promising specific combinations. Populations 24 and 36 were indicated for interpopulational breeding programs. Diallelic crosses among ten tropical early and intermediate populations and/or pools were evaluated at nine locations by Beck et al. (1990). They suggested Population 23 and Pool 20 (white kernels) and Population 26 and Pools 21 and 22 (yellow kernels) as the best promising sources for hybrid development.

\section{Latin American Maize Project (LAMP)}

LAMP is a real example of pre-breeding program, which includes 12 countries (Argentina, Bolivia, Brazil, Colombia, Chile, U.S., Guatemala, Mexico, Paraguay, Peru, Uruguay and Venezuela). LAMP evaluated 15,000 accessions in the first stage, with close cooperation of the public and private sectors. Pioneer Hi-Bred International Company was decisive for the financial support of the project. The great genetic variability in Latin American maize is recognized, although there is much to be known, especially its potential and its significance for breeding approaches. There is also little available information concerning agronomic traits.
LAMP was carried out in five stages over a 5-year period. In stage 1 each accession selected in each country was grown with two replications at a single location. In stage 2 only the top 20\% evaluated accessions were planted in two locations with two replications and the upper $5 \%$ were selected. Selected materials were interchanged among countries in stage 3 . They were planted at each partner's country in two locations and with two replications; they were also crossed with an adapted local tester in an isolated field. In stages 4 and 5, experiments were conducted to test the combining ability of the selected accessions with the adapted testers. Evaluations for resistance to disease and tolerance to climatic and soil conditions were also planned. Pollak (1993) showed the results of 562 Caribbean maize accessions obtained in Puerto Rico. Grain yield of the best $20 \%$ ranged from 3,937 to $7,773 \mathrm{~kg} \mathrm{ha}^{-1}$, and 18 accessions out yielded the check "Diente de Caballo", a local improved variety. Accessions with good ear quality and grain yield were identified for use in the Caribbean and other tropical breeding programs. In Brazil, 1,111 accessions fulfilled the conditions required by LAMP (minimum of $1 \mathrm{~kg}$ of seeds and viability $>75 \%$ ), and all adapted to altitude under $2000 \mathrm{~m}$. TABLE 3 shows the selected accessions after two years of evaluations at different locations in Brazil (M.X. Santos Pers. Comm.). It can be seen that several accessions showed high grain yield besides other important agronomic traits like low ear height and earliness.

Other important pre-breeding program was developed in specific areas of Brazil, where several diseases limited maize production. The Department of Genetics of the "Escola Superior de Agricultura Luiz de Queiroz" - SP, Brazil, coordinates a Supporting Maize Research Nucleus (NAP-Milho) which is accomplishing an extensive germplasm evaluation regarding their reaction to the main diseases prevalent in Brazil. In the first stage about 1,300 accessions and 140 maize populations are being evaluated at 13 representative locations. Priority has been given to Exserohilum turcicum, Puccinia polysora, Physophella zeae, Phaeosphaeria maydis, and Corn Stunt complex. The most promising materials will be combined to obtain new resistant populations.

\section{Problems to be investigated and suggestions}

Environmental conditions for maize in the tropics are widely variable. Edaphic and climatic variations are found among and within different regions. Socioeconomic differences are also found among regions, as well as among farmers, within these regions (Paterniani, 1990). All these factors indicate that tropical conditions for a good corn crop are more adverse then those found in temperate areas. Consequently, problems of breeding are more numerous and more complex. Since most of the local cultivars seldom possess the required characteristics for the different growing conditions, pre-breeding programs for some specific traits should be conducted locally. Priority should be given to the following characteristics: 1) plant 
TABLE 3 - Some characteristics of selected maize accessions according by LAMP's stage 1 and 2 in Brazil.

\begin{tabular}{|c|c|c|c|c|c|c|c|c|}
\hline \multirow[t]{2}{*}{ Accession Code } & \multirow[t]{2}{*}{ Identification } & \multicolumn{2}{|c|}{ Days to Flower } & \multirow[t]{2}{*}{$\begin{array}{l}\text { Plant } \\
\text { Height }\end{array}$} & \multirow[t]{2}{*}{$\begin{array}{l}\text { Ear } \\
\text { Height }\end{array}$} & \multirow[t]{2}{*}{$\begin{array}{l}\text { Yield 15\% } \\
\text { moisture }\end{array}$} & \multirow[t]{2}{*}{$\begin{array}{c}\text { Endosperm } \\
\text { Type }\end{array}$} & \multirow[t]{2}{*}{ Grain Color } \\
\hline & & Male & Female & & & & & \\
\hline & & & & ----- C & 1---- & $\mathrm{kg} \mathrm{ha}^{-1}$ & & \\
\hline BRA 024767 & Brasil 2296 & 67 & 73 & 185 & 100 & 3,547 & Flint & Yellow \\
\hline BRA 054241 & Asteca & 59 & 65 & 190 & 115 & 3,469 & Dent & Yellow \\
\hline BRA 044369 & 31136 Comp & 64 & 69 & 140 & 60 & 3,183 & Dent & Yellow \\
\hline BRA 044318 & 31116 Comp & 69 & 73 & 150 & 75 & 3,150 & Dent & Yellow \\
\hline BRA 053627 & Caiano & 69 & 72 & 185 & 115 & 2,938 & Dent & Yellow \\
\hline BRA 028029 & CMS 06 & 70 & 71 & 227 & 97 & 6,908 & Dent & Yellow \\
\hline BRA 031381 & Tuxpeño 1 & 70 & 72 & 199 & 78 & 5,988 & Dent & White \\
\hline BRA 051501 & PE 011 * & - & 71 & 225 & 125 & 3,214 & Dent & Yellow \\
\hline BRA 050598 & AL 015 & - & 69 & 210 & 115 & 3,106 & Semi-dent & Yellow \\
\hline BRA 051675 & PE 027 & - & 67 & 215 & 105 & 3,015 & Dent & Yellow \\
\hline BRA 050024 & Comp. Manaus * & - & 70 & 210 & 125 & 2,990 & Semi-flint & Yellow \\
\hline BRA 052060 & SE 033 & - & 74 & 210 & 125 & 2,965 & Dent & Yellow \\
\hline BRA 051721 & RN 004 & - & 67 & 220 & 120 & 3,068 & Dent & Yellow \\
\hline BRA 051764 & SE 003 & - & 72 & 245 & 140 & 3,000 & Semi-dent & Yellow \\
\hline BRA 052019 & SE 028 & - & 69 & 210 & 130 & 2,892 & Semi-dent & Yellow \\
\hline BRA 052051 & SE 032 & - & - & 240 & 150 & 2,328 & Dent & Orange \\
\hline BRA 051501 & PE 011 * & 60 & 61 & 294 & 148 & 6,873 & Dent & Yellow \\
\hline BRA 030929 & BA 157 & 62 & 65 & 274 & 151 & 5,508 & Dent & Yellow \\
\hline BRA 051039 & BA 038 & 62 & 62 & 256 & 125 & 5,857 & Dent & Yellow \\
\hline BRA 052957 & Flint Composto & 61 & 62 & 263 & 135 & 5,362 & Flint & Yellow \\
\hline BRA 050024 & Comp. Manaus * & 59 & 61 & 239 & 109 & 6,101 & Semi-flint & Yellow \\
\hline BRA 051403 & PE 001 & 64 & 63 & 241 & 131 & 4,924 & Flint & Orange \\
\hline BRA 044083 & Comp. Jaiba III & 61 & 62 & 228 & 115 & 5,473 & Semi-flint & Yellow \\
\hline BRA 043915 & CMS 0508 III & 65 & 67 & 208 & 88 & 3,950 & Semi-flint & Yellow \\
\hline
\end{tabular}

${ }^{*}$ Accessions selected in two site

and ear height, since generally tropical materials have tall plants with ear placement high on the stalks; 2) prolificacy, which is highly correlated to grain yield; 3 ) tassel size, since is negatively correlated to yield and tropical maize cultivars frequently have large tassels (25 to 35 branches) ; 4) disease resistance, nowadays, the main problem in Brazil; 5 ) insect resistance, also a great problem in tropical and subtropical areas; 6) drought tolerance, since the growing season in tropical and subtropical areas is characterized by erratic variations of rainfall; 7 ) tolerance to aluminum toxicity, important for specific areas and several contributions have shown the presence of genetic variability in maize for Al tolerance; 8) nutritional quality, particularly important for developing countries; 9) low temperature tolerance, especially as a strategy for growing maize in subtropical areas, such as in South of Brazil; 10) other traits, such as nitrogen and phosphorus utilization efficiency, earliness, photosynthetic efficiency, and stalk quality.
Both public and private sectors should be involved in pre-breeding programs. Another important point is the time-consuming to develop these activities. Promising results can certainly be obtained in five to ten years, considering the level of available information on materials at the beginning of the program. Certainly, pre-breeding activities will improve the knowledge about the accessions maintained in germplasm banks and will contribute to reduce the gap between available genetic resources and maize breeding programs.

\section{REFERENCES}

BECK, D.L.; VASAL, S.K.; CROSSA, J. Heterosis and combining ability of CIMMYT's tropical early and intermediate maturity maize (Zea mays L.) germplasm. Maydica, v.35, p.279-285, 1990.

BRIDGES JR., W.C.; GARDNER, C.O. Foundation populations for adapted by exotic crosses. Crop Science, v.27, p.501-506, 1987. 
BRIEGER, F.G.; GURGEL, J.T.A.; PATERNIANI, E.; BLUMENSCHEIN, A.; ALLEONI, M.R. Races of maize in Brazil and other eastern South America countries. Washington, 1958. (NAS-NRC, 593)

BROWN, W.L. A broader germplasm base in corn and sorghum. Proceedings Annual Corn and Sorghum Research Conference, v.30, p.81-89, 1975.

BROWN, A.H.D. The case for core collections. In: BROWN, A.D.H.; FRANKEL, O.H.; MARSHALL, D.R. ; WILLIAMS, J.T. (Ed.) The use of plant genetic resources. Cambridge: University Press, 1989a. p.136-156

BROWN, A.H.D. Core collections: a practical approach to genetic resources management. Genome, v.31, p.818-824, 1989b.

CHANG, T.T.. Availability of plant germplasm for use in crop improvement. In: STALKER, H.T.; MURPHY, J.P. (Ed.) Plant breeding in the 1990s. Melksham: Redwood Press, 1992. p.17-35.

CROSSA, J. Theoretical considerations for the introgression of exotic germplasm into adapted maize populations. Maydica, v.34, p.53-62, 1989.

CROSSA, J.; GARDNER, C.O. Introgression of an exotic germplasm for improving an adapted maize population. Crop Science, v.27, p.187-190, 1987

CROSSA, J.; GARDNER, C.O.; MUMM, R.F. Heterosis among populations of maize (Zea mays L.) with different levels of exotic germplasm. Theoretical Applied Genetics, v.73, p.445-450, 1987.

CROSSA, J.; TABA, S.; WELLHAUSEN, E.J. Heterotic patterns among Mexican races of maize. Crop Science, v.30, p.11821190, 1990.

CROSSA, J.; VASAL, S.K.; BECK, D.L. Combining ability estimates of CIMMYT's tropical late yellow maize germplasm. Maydica, v.35, p.273-278, 1990.

CROSSA, J.; TABA, S.; EBERHART, S.A.; BRETTING, P.; VENCOVSKY, R. Practical considerations for maintaining germplasm in maize. Theoretical Applied Genetics, v.89, p.89-95, 1994.

DOWSWELL, C.R.; PALIWAL, R.L.; CANTRELL, R.P. Maize in the third world. Boulder: Westview Press, 1996.

DUDLEY, J.W. Theory for transfer of alleles. Crop Science, v.22, p.631-637, 1982

DUVICK, D.N. Genetic diversity in major farm crops on the farm and in reserve. Economic Botany, v.38, p.161-178, 1984.

EBERHART, S.A. Regional maize diallels with U.S. and semiexotic varieties. Crop Science, v.11, p.911-914, 1971.

EBERHART, S.A.; SALHUANA, W.; SEVILLA, W. R.; TABA, S. Principles for tropical maize breeding. Maydica, v.40, p.339-355, 1995.

GOODMAN, M.M. Genetic and germplasm stocks worth conserving. Journal of Heredity, v.81, p.11-16, 1990.

HALLAUER, A.R. Potential of exotic germplasm for maize improvement. In: WALDEN, D.B. (Ed.) Maize breeding and genetics. New York: John Wiley, 1978. p.229-247.

HALLAUER, A.R.; MIRANDA FILHO, J.B. Quantitative genetics in maize breeding. Ames: lowa University Press, 1988.

HALLAUER, A.R.; RUSSELL, W.A.; LAMKEY, K.R. Corn breeding. In: SPRAGUE, G.F.; DUDLEY, J.W. (Ed.) Corn and corn improvement. Madison: American Society of Agronomy, 1988. p.463-563.

LONNQUIST, J.H. Consideration and experiences with recombinations of exotic and Corn Belt maize germplasms. In: ANNUAL CORN AND SORGHUM RESERACH CONFERENCE, 29., Chicago, 1974. Proceedings. Washington: American Seed Trade Association, 1974. p.102-117.
MARSHALL, D.R. Limitations to the use of germplasm collections. In: BROWN, A.D.H.; FRANKEL, O.H.; MARSHALL, D.R.; WILLIAMS, J.T. (Ed.) The use of plant genetic resources. Cambridge: University Press, 1989. p. 105-120.

MICHELINI, L.A.; HALLAUER, A.R. Evaluation of exotic and adapted maize (Zea mays L.) germplasm crosses. Maydica, v.38, p.275-282, 1993.

MUNGOMA C.; POLLAK, L.M. Heterotic patterns among ten Corn Belt and exotic maize germplasm. Crop Science, v.28, p.500-504, 1988

NASS, L.L.; PELLICANO, I.J.; VALOIS, A.C.C. Utilization of genetic resources for maize and soybean breeding in Brazil. Brazilian Journal of Genetics, v.16, p.983-988, 1993.

PANDEY, S.; GARDNER, C.O. Recurrent selection for population, variety, and hybrid improvement in tropical maize. Advances in Agronomy, v.48, p.1-87, 1992.

PARKS, J.S. Genetic minimum distance for corn: an update from the ASTA corn variety identification subcommitte. In: ANNUAL CORN AND SHORGHUM RESEARCH CONFERENCE, 48. Chicago, 1993. Proceedings. Washington: American Trade Association, 1993. p.16-29.

PATERNIANI, E. An evaluation of the genetic diversity in the varieties currently utilized. In: PLANT Breeding Research Forum; report 1985. Caracas, 1987. p.45-58.

PATERNIANI, E. Maize breeding in the tropics. CRC Critical Review in Plant Science, v.9, p.125-154, 1990.

PATERNIANI, E.; LONNQUIST, J.H. Heterosis in interracial crosses of corn (Zea mays L.). Crop Science, v.3, p.504-507, 1963.

PATERNIANI, E.; GOODMAN, M.M. Races of maize in Brazil and adjacent areas. Mexico: CIMMYT, 1977.

PEETERS, J.P.; GALWEY, N.W. Germplasm collections and breeding needs in Europe. Economic Botany, v.42, p.503-521, 1988

POLLAK, L.M. Evaluation of Caribbean maize accessions in Puerto Rico. Tropical of Agriculture, v.70, p.8-12, 1993.

SALHUANA, W. Strategies for increasing the use of germplasm. In: PLANT Breeding Research Forum; report 1985. Caracas, 1987. p.141-172.

SMITH, J.C.S.; DUVICK, D.N. Germplasm collections and the private plant breeder. In: BROWN, A.D.H.; FRANKEL, O.H.; MARSHALL, D.R.; WILLIAMS, J.T. (Ed.) The use of plant genetic resources. Cambrigde: University Press, 1989. p.17-31.

TABA, S. 1994. The future : needs and activities. In: TABA, S. (Ed.) The CIMMYT maize germplasm bank: genetic resource preservation, regeneration, maintenance, and use. Mexico, 1994. p.52-59. (Maize Program Special Report)

TABA, S.; PINEDA, F.E.; CROSSA, J. Forming core subsets from the Tuxpeño race complex. In: TABA, S. (Ed.) The CIMMYT maize germplasm bank: genetic resource preservation, regeneration, maintenance, and use. Mexico, 1994. p.60-81. (Maize Program Special Report)

TROYER, A.F. A retrospective view of corn genetic resources. Journal of Heredity, v.81, p.17-24, 1990.

VILELA-MORALES, E.A.; VALOIS, A.C.C.; NASS, L.L. Recursos genéticos vegetales. Brasília: Embrapa, SPI: Embrapa,Cenargen, 1997.

WELLHAUSEN, E.J. 1965. Exotic germplasm for improvement of Corn Belt maize. In: ANNUAL HYBRID CORN INDUSTRY RESEARCH CONFERENCE, 20., Chicago, 1965. Proceedings. Washington: American Seed Trade Association, 1965. p.31-45.

$\overline{\text { Received March }}$ 20, 2000 